\title{
PENEGAKAN HUKUM TERHADAP PENGEDAR NARKOTIKA DENGAN BERAT NETTO 36 GRAM (STUDI KASUS: PUTUSAN PENGADILAN NEGERI JAKARTA SELATAN NOMOR 637/Pid.sus/2015/PN.JKT.SEL)
}

\author{
Clarissa Meidy Paulus \\ (Mahasiswa Program S1 Fakultas Hukum Universitas Tarumanagara) \\ (E-mail: paulus.clarissa@yahoo.com)
}

\section{Dian Andriawan Daeng Tawang}

(Corresponding Author)

(Dosen Hukum Pidana, Universitas Tarumanagara dan Universitas Trisakti, Meraih Sarjana Hukum dari Universitas Hasanuddin, Magister Hukum dari Universitas Hasanuddin, dan Doktor Ilmu Hukum dari Universitas Hasanuddin)

(E-mail: Dianadriawan@yahoo.com)

\begin{abstract}
Due to a rise in cases related to narcotics in Indonesia, the government is stiffening penalties for drug offences. Now, anyone who violates certain drug laws in the nation may end up serving a minimum of four years prison time. Depending on the severity of the violations, the government may even sentence more drug offenders to death. Examines the impact of globalization and new technology on the narcotics industry. Examines the challenges that new technologies, such as the internet, pose to drug law enforcement. Illicit trafficking of narcotics has been very widespread in Indonesia, Similarly, what happens in this case, someone who ordered narcotics from America-Indonesia. This transaction is done online, But in this case the judge handed down the rehabilitation decision to the narcotics dealer. The order made by the defendant is narcotics with a net weight of 36.1318 grams. From the results of this study based on interviews conducted if giving narcotics to other people with or without the transaction can already be declared as a dealer. Millions of people are affected by drugs in Indonesia. According to the National Agency for Narcotics (BNN), one million people are addicted to drugs with little chance of recovery. Around 1.6 million people occasionally take drugs while 1.4 million are regularly consumers.

Keywords: Narcotics, Illicit trafficking, Dealer, Penalties
\end{abstract}




\section{PENDAHULUAN}

\section{A. Latar Belakang}

Pada saat ini peredaran gelap narkotika dapat dilakukan dengan berbagai cara. Salah satu cara yang digunakan adalah dengan menggunakan jasa pengiriman melalui PT Pos Indonesia. Pemesanan narkotika juga bukanlah hal yang sulit pula untuk dilakukan. Pemesanan dapat dilakukan secara online. Bagi kalangan muda bukanlah hal yang tabu lagi untuk melakukan transaksi jual-beli secara online, karena perkembangan teknologi yang sangat pesat ini pun banyak orang sekarang melakukan transaksi jual-beli secara online tanpa diperlukannya suatu pertemuan. Suatu transaksi jual-beli online bukanlah hal yang negatif untuk dilakukan, namun bagaimana apabila jaringan ini dilakukan oleh pihak yang tidak bertanggung jawab. Apalagi hal ini sangat mempermudah jaringan pengedar narkotika dalam menjual obat-obatan terlarang tersebut.

Peredaran gelap ini dapat dilakukan dengan cara menyelundupkan narkotika yang telah dibeli secara online dan dikirim dengan menggunakan Pos Indonesia ataupun dengan cara Transito Narkotika. Transito Narkotika adalah pengangkutan narkotika dari suatu negara ke negara lain dengan melalui dan singgah di wilayah Negara Republik Indonesia yang terdapat kantor pabean dengan atau tanpa berganti sarana angkutan.

Narkotika pada mulanya ditemukan orang untuk kepentingan umat manusia, khususnya di bidang pengobatan. Narkotika merupakan zat atau obat yang sangat bermanfaat dan diperlukan untuk pengobatan penyakit tertentu. Dalam perkembangannya diketahui bahwa zat-zat yang terdapat dalam narkotika memiliki daya kecanduan yang dapat menimbulkan si pemakai bergantung hidupnya terus menerus pada narkotika. Sehingga penggunannya kini sering disalahgunakan bukan lagi untuk kepentingan pengobatan, melainkan untuk menguntungkan pihak-pihak tertentu dan dapat mengancam generasi suatu bangsa. ${ }^{1)}$

\footnotetext{
1) Taufik Makarao, Tindak Pidana Narkotika, (Jakarta: Ghalia Indonesia, 2003), hal.17-19.
} 
Penyebaran narkotika di Indonesia sangat meluas dan juga meresahkan masyarakat. Direktur Reserse Narkoba Polda Metro Jaya Kombes Nico Afinta mengatakan, mayoritas pengguna narkoba di Indonesia berada di Jakarta. Berdasarkan data dari Badan Narkotika Nasional (BNN) jumlah pengguna narkoba di Indonesia bisa mencapai 5 juta orang. Namun 600.000-1,2 juta pengguna narkotika ada di Jakarta. ${ }^{2)}$ Indonesia bukan hanya tempat transit narkotika dan obat-obatan berbahaya tetapi juga menjadi produsen dan daerah pemasarannya. Fatalnya, narkoba kini sudah menjamah berbagai lapisan masyarakat termasuk kalangan terdidik dan aparat penegak hukum. ${ }^{3)}$

Penegakan hukum dan keadilan merupakan serangkaian proses yang cukup panjang dan dapat melibatkan berbagai kewenangan instansi/aparat penegak hukum lainnya (di bidang penegakan hukum pidana melibatkan aparat penyidik/kepolisian, aparat penuntut umum/kejaksaan, aparat pengadilan, dan aparat pelaksana pidana). ${ }^{4}$ Penegakan hukum terhadap tindak pidana narkotika telah banyak dilakukan oleh aparat penegak hukum dan telah banyak mendapat putusan hakim. Dengan demikian, penegakan hukum ini diharapkan mampu menjadi faktor penangkal terhadap merebaknya perdagangan gelap serta peredaran narkotika. Tapi dalam kenyataannya justru semakin intensif dilakukan penegakan hukum, semakin meningkat pula peredaran serta perdagangan gelap narkotika tersebut.

Pidana seharusnya lebih dititikberatkan kepada pengedar narkotika karena dengan adanya pengedar yang menyebabkan munculnya penyalahguna narkotika yang kemudian melahirkan seorang pecandu narkotika, karena biar bagaimanapun pemberantasan narkotika harus dilihat titik sentralnya, sulitnya aparat penegak hukum melakukan pelacakan terhadap pengedaran narkotika di karenakan kejahatan tersebut dilakukan tidak secara perseorangan melaikan melibatkan banyak orang yang secara

2) Akhdi Martin Pratama, "Pengguna Narkoba di Jakarta Mencapai 1,2 Juta Orang", Kompas, 24 Juli 2017, hal.1.

3) O.C.Kaligis dan Associates, Narkoba dan Peradilannya di Indonesia, (Bandung: Alumni, 2002), hal.292.

4) Barda Nawawi Arief, Masalah Penegakan Hukum dan Kebijakan Hukun Pidana dalam Penanggulangan Kejahatan, (Jakarta: Kencana Prenada Media Group, 2008), hal.4. 
bersama-sama bahkan merupakan satu sindikat yang terorganisasi dengan jaringan luas yang bekerja secara rapi dan sangat rahasia baik di tingkat nasional maupun internasional. ${ }^{5)}$

Dalam pengadilan yang menangani kasus narkotika diperlukannya ketegasan dan keadilan bagi hakim dalam memberikan putusan. Hakim pada dasarnya memiliki peran dan posisi yang sangat sentral dalam penegakan hukum dan keadilan. ${ }^{6)}$ Baik putusan dengan dikenakannya pidana mati, penjara seumur hidup, penjara denda hingga dimungkinkan sanksi berupa rehabilitasi Dalam Pasal 113 Ayat (2) UU Narkotika dinyatakan bahwa:

"Dalam hal perbuatan memproduksi, mengimpor, mengekspor, atau menyalurkan Narkotika Golongan I sebagaimana dimaksud pada ayat (1) dalam bentuk tanaman beratnya melebihi 1 (satu) kilogram atau melebihi 5 (lima) batang pohon atau dalam bentuk bukan tanaman beratnya melebihi 5 (lima) gram, pelaku dipidana dengan pidana mati, pidana penjara seumur hidup, atau pidana penjara paling singkat 5 (lima) tahun dan paling lama 20 (dua puluh) tahun dan pidana denda maksimum sebagaimana dimaksud pada ayat (1) ditambah $1 / 3$ (sepertiga)."

Hal yang berbeda terjadi pada Putusan Pengadilan Negeri Jakarta Selatan Nomor 637/Pid.sus/2015/PN.JKT.SEL yang mengacu pada pasal ini. Pada tahun 2004 terjadi transaksi jual-beli online dari Amerika-Indonesia. Tiga anak muda membeli secara online dari Amerika Narkotika Golongan I, lalu barang pesanan diselundupkan ke Indonesia melalui pengiriman. Sesampai di Indonesia saat dilakukan $x$-ray pada tahun 2009 bulan Oktober yang dilakukan oleh petugas bea cukai dan petugas kantor pos karena merasa janggal dengan barang pengiriman tersebut. Bulan November 2014 hasil lab dari Balai Pengujian dan Identifikasi Barang (BPIB) menyatakan bahwa barang tersebut positif narkotika dengan Berat Netto 36,1318 gram. Terjadilah penangkapan pada bulan November 2014 di kantor Pos Fatmawati Jakarta Selatan pada saat petugas kantor pos mengirim surat panggilan kepada terdakwa untuk

\footnotetext{
${ }^{5)}$ Lilik Mulyadi, "Pemidanaan Terhadap Pengedar dan Penggunan Narkoba", Jurnal Hukum dan Peradilan, Edisi No. 1 Tahun 2012, hal.315.

6) Komisi Yudisial Republik Indonesia, Membumikan Tekad Menuju Peradilan Bersih, (Jakarta: Komisi Yudisial Republik Indonesia, 2011), hal.123.
} 
menggambil paket tersebut. Namun, penerapan Pasal 113 Ayat (2) ini tidak dijatuhkan pada terdakwa, karena hakim menjatuhkan putusan terhadap terdakwa hanya dijatuhi masa hukuman rehabilitasi selama 1 (Satu) tahun.

Adanya suatu perbedaan terhadap Putusan Pengadilan Negeri Jakarta Utara Nomor 273/Pid.Sus/2016/PN.JKT.UTARA. Seorang tertangkap tangan menggunakan Narkotika Golongan I bukan tanaman dengan Berat Netto 0,0880 gram, lalu ditemukan lagi narkotika jenis shabu ini dalam 3 bungkus plastik klip yang berbeda dengan Berat Netto seluruhnya 0,0789 gram, direncanakan oleh terdakwa untuk dijual kepada orang lain dengan harga Rp.200.000,-/klip. Namun hakim dalam putusan ini menjatuhkan masa hukuman selama 4 tahun 6 bulan dan dikenakan denda Rp.800.000.000,-. Di mana hal ini sesuai dengan Pasal 112 Ayat (1) yang berisi:

"Setiap orang yang tanpa hak atau melawan hukum memiliki, menyimpan, menguasai, atau menyediakan Narkotika Golongan I bukan tanaman, dipidana dengan pidana penjara paling singkat 4 (empat) tahun dan paling lama 12 (dua belas) tahun dan pidana denda paling sedikit Rp.800.000.000,(delapan ratus juta rupiah) dan paling banyak Rp.8.000.000.000,- (delapan miliar rupiah)."

Dilihat dari kedua putusan ini terjadi suatu hal yang menjanggal, karena dari Putusan Pengadilan Negeri Jakarta Utara Nomor 273/Pid.Sus/2016/PN.JKT.UTARA yang menggunakan Narkotika Golongan I ini dengan Berat Netto 0,0880 gram dipidana penjara selama 4 tahun 6 bulan, sedangkan Putusan Pengadilan Negeri Jakarta Selatan Nomor 637/Pid.sus/2015/PN.JKT.SEL yang mengimpor, mengekspor, atau menyalurkan Narkotika Golongan I dengan Berat Netto 36,1318 gram hanya dikenakan masa hukuman rehabilitasi selama 1 (satu) tahun. Adanya suatu hal yang menjanggal pada penerapan hukum hakim dalam menjatuhkan pidana terhadap pengedar narkotika ini sudah sesuai dengan UU Narkotika, karena terjadinya suatu perbedaan antara penerapan hukum dengan undang-undang yang sudah ada.

Maka Berdasarkan latar belakang di atas maka penulis tertarik untuk membuat jurnal dengan judul: "PENEGAKAN HUKUM TERHADAP PENGEDAR NARKOTIKA DENGAN BERAT NETTO 36 GRAM (STUDI KASUS: 


\section{PUTUSAN PENGADILAN NEGERI JAKARTA SELATAN NOMOR 637/Pid.sus/2015/PN.JKT.SEL)“.}

\section{B. Permasalahan}

Berdasarkan latar belakang yang dikemukakan di atas, maka permasalahan yang dapat dirumuskan sebagai berikut:

1. Bagaimana aspek penegakan hukum terhadap pengedar narkotika dengan berat netto 36 gram pada Putusan Pengadilan Negeri Jakarta Selatan Nomor 637/Pid.Sus/2015/PN.JKT.SEL?

2. Mengapa hakim menjatuhkan putusan rehabilitasi terhadap pengedar narkotika dengan berat netto 36 gram pada Putusan Pengadilan Negeri Jakarta Selatan Nomor 637/Pid.Sus/2015/PN.JKT.SEL?

\section{Metode Penelitian}

Penelitian merupakan sarana yang dipergunakan oleh manusia untuk memperkuat, membina serta mengembangkan ilmu pengetahuan. Ilmu pengetahuan yang merupakan pengetahuan yang tersusun secara sistematis dengan penggunaan kekuata pemikiran, pengetahuan mana senantiasa dapat diperiksa dan ditelaah secara kritis, akan berkembang terus atas dasar penelitian-penelitian. ${ }^{7)}$

\section{Jenis Penelitian}

Metode penelitian yang Penulis gunakan adalah metode penelitian hukum empiris/sosiologis, yang dimaksud penelitian hukum empiris/sosiologis adalah suatu penelitian hukum yang sumber datanya diperoleh dari data primer atau data yang diperoleh langsung dari masyarakat. ${ }^{8)}$ Kajian empiris adalah kajian yang memandang

\footnotetext{
7) Soerjono Soekanto, Pengantar Penelitian Hukum, (Jakarta: Universitas Indonesia, 2006), hal.3.

${ }^{8)}$ Ronny Hanitijo Soemitro, Metodologi Penelitian Hukum, (Jakarta: Ghalia Indonesia, 1983), hal.24.
} 
hukum sebagai kenyataan, mencangkup kenyataan sosial, kenyataan kultur, dan lainlain. Kajian ini bersifat deskriptif. ${ }^{9)}$

\section{Sifat Penelitian}

Penelitian yang akan dilakukan bersifat deskriptif, yaitu suatu penelitian yang berusaha untuk memperoleh gambaran dan penjelasan mengenai masalah yang diteliti. ${ }^{10)}$ Penulis akan menjelaskan mengenai penegakan hukum yang seharusnya dilakukan oleh hakim dalam menjatuhkan suatu putusan terhadap pengedar narkotika apakah telah sesuai dengan UU Narkotika, dengan melakukan wawancara terhadap narasumber (beberapa penegak hukum seperti penyidik, hakim, penasehat hukum/advokat, pihak BNN).

\section{Jenis Data}

Secara umum, maka di dalam penelitian biasanya dibedakan antara data yang diperoleh secara langsung dari masyarakat dan dari bahan pustaka. Data yang diperoleh langsung dari masyarakat dinamakan data primer atau data dasar dan data yang kedua diberi nama data sekunder. ${ }^{11)}$ Pada penelitian hukum empiris/sosiologis, maka yang diteliti pada awalnya adalah data sekunder untuk kemudian dilanjutkan dengan penelitian terhadap data primer lapangan, atau terhadap masyarakat. ${ }^{12)}$ Data sekunder yang diteliti, mencangkup:

a. Bahan hukum primer, yaitu bahan-bahan hukum yang mengikat, seperti peraturan perundang-undangan, yaitu Undang-undang Narkotika, Undang-undang Kekuasaan Kehakiman, KUHAP serta putusan pengadilan yang berkaitan dengan isu hukum yang dihadapi.

b. Bahan hukum sekunder, merupakan bahan hukum yang sudah diperoleh dari sumber yang sudah diketemukan oleh peneliti sebelumnya. Kegunaan bahan hukum

\footnotetext{
9) Achmad Ali dan Wiwie Heryani, Menjelajahi Kajian Empiris Terhadap Hukum, (Jakarta:
} Kencana Prenada Media Group, 2012), hal.2.

${ }^{10)}$ Soerjono Soekanto, Op.Cit., hal.53.

11) Ronny Hanitijo Soemitro, Op.Cit., hal.51.

12) Ibid., hal.52. 
sekunder memberikan kepada Penulis semacam "petunjuk" ke arah mana Penulis melangkah seperti dari artikel, majalah, jurnal, serta data yang diperoleh dari internet. c. Bahan hukum Tersier adalah bahan hukum yang memberikan petunjuk maupun penjelasan terhadap bahan hukum primer dan sekunder yaitu berupa Kamus Besar Bahasa Indonesia, dan Kamus Hukum untuk membantu Penulis dalam memberikan pendapat dengan menggunakan bahasa yang baik dan benar.

\section{Teknik Pengumpulan Data}

Usaha yang akan dilakukan untuk mengumpulkan data primer, Penulis menggunakan teknik wawancara secara langsung dengan para narasumber, yaitu wawancara dengan pengurus Badan Narkotika Nasional, hakim, penyidik dan advokat/penasehat hukum yang bersedia untuk memberikan pendapat mereka terhadap kasus yang akan Penulis analisis.

\section{Teknik Analisis Data}

Semua data yang dikumpulkan baik data primer maupun data sekunder akan dianalisis secara kualitatif yaitu uraian menurut mutu, yang berlaku dengan kenyataan sebagai gejalan data primer yang dihubungkan dengan teori dalam data sekunder. Data disajikan dengan menjelaskan dan mengumpulkan permasalahan-permasalahan yang terkait dengan penulisan skripsi ini.

\section{PEMBAHASAN}

\section{A. Hasil Penelitian}

Sesuai dengan metode penelitian yang Penulis gunakan adalah metode penelitain empiris maka dari itu Penulis melakukan wawancara oleh beberapa narasumber dari aparat penegakan hukum di Jakarta. Salah satunya adalah Sugandi Ishak, S.H., M.H dosen fakultas hukum Universitas Tarumanagara, beliau juga adalah seorang anggota PERADI, menurut beliau penegakan hukum yang terdapat dalam Putusan Pengadilan Negeri Jakarta Selatan Nomor 637/Pid.sus/2015/PN.JKT.SEL yang seharusnya di permasalahkan karena dalam Surat Edaran Mahkamah Agung Nomor 4 Tahun 2010 (untuk selanjutnya disebut SEMA) yang dapat di rehabilitasi itu dibawah 0,6 gram. 
Hal ini pun mempunyai jangka waktu 1 (satu) minggu putusannya kalau memang ingin di rehabilitasi. Tapi kalau diatas 0,6 gram tidak ada ketentuan untuk dilakukannya rehabilitasi.

Rehabilitasi ini bisa saja putusan pada tahap penyidikan atau pada tahap BNN, tapi bisa juga rehabilitasi dilakukan dengan putusan bersama antara jaksa, kepolisian, BNN atau instansi terkait. Sangat jarang dan tidak banyak keputusan dari kejaksaan atau bersama. Hanya untuk kasus ini dengan berat 36,1318 gram seharusnya tidak boleh di rehabilitasi. Seharusnya dengan sudah adanya ketentuan Mahkamah Agung hakim harus tunduk pada peraturan ini. ${ }^{13)}$

Hal serupa juga didukung oleh Silas Dutu, S.H., M.H. seorang advokat yang menyatakan bahwa Putusan hakim yang terdapat pada kasus ini tidak tepat karena perkara ini berawal dari terdakwa sebagai seorang pengimpor dan jelas bahwa barang bukti narkotika ini asalnya bukan dari Indonesia melainkan dari Amerika, sudah jelas bahwa terdakwa sebagai pengimpor. Apabila majelis hakim menjatuhkan putusan bahwa terdakwa ini penyalahguna, sangat tidak tepat dengan adanya bukti-bukti yang terlampir.

Barang narkotika ini sudah diselundupkan dengan cara mengimpor dan seharusnya majelis hakim menerapkan Pasal 113 UU Narkotika. Sudah sangat jelas bahwa terdakwa terbukti secara meyakinkan sebagai pengimpor, terbukti juga bahwa barang ini diantar dengan pihak imigrasi. Terdakwa seharusnya dijatuhi hukuman Pasal 113 UU Narkotika ini, tidak tepat apabila terdakwa dijatuhi putusan rehabilitasi.

Sudah terbukti bahwa terdakwa adalah seorang pengedar dari keterangan saksi yang terdapat dalam putusan bahwa terdakwa pernah memberikan narkotika kepada seorang temannya yang putusannya terpisah walaupun tanpa adanya transaksi jualbeli tetapi secara hukum ketika terdakwa mengedarkan itu maka terdakwa sudah

\footnotetext{
${ }^{13)}$ Hasil Wawancara
} 
terbukti sebagai pengedar, juga terbukti bahwa terdakwa pengimpor, dan jumlah barang bukti nya tidak sedikit. ${ }^{14)}$

Menurut dr. Wahyu Wulandari, M.Si. kepala bidang rehabilitasi di BNN menyatakan bahwa syarat-syarat seseorang dapat di rehabilitasi adalah dilihat dari satu tahun terakhir adanya riwayat pemakaian, tapi akan di periksa terlebih dahulu yaitu asesmen yang merupakan untuk diketahuinya tingkat ketergantungan seseorang, dari asesmen ini akan dilihat apakah orang tersebut membutuhkan rehabilitasi rawat jalan atau rawat inap.

Apabila dilihat dari SEMA maka pelaksanaan rehabilitasi harus sesuai dengan ketentuan yang terdapat pada SEMA, sedangkan dalam kasus dinyatakan terdapat 36 gram dan di SEMA hanya 5 gram maka putusan hakim dalam menjatuhkan rehabilitasi tidak tepat. Hal yang dapat membuat seseorang kecanduan itu dari zat nya tapi dapat dilihat pula dari faktor eksternal dan internal, tetapi hal yang lebih sulit dilihat dari faktor internal seperti adanya zat tertentu yang tingkat kecanduannya lebih besar seperti heroin.

Penegakan hukum yang terdapat pada kasus ini dimana seorang pengedar di rehabilitasi sangat tidak wajar, tapi biasanya apabila adanya seorang pengedar yang ingin di rehabilitasi akan dilakukan di LAPAS tersebut. Memang sangat sulit bagi tim asesmen terpadu BNN untuk membedakan pengedar dan pecandu karena itu merupakan tugas penyidik. Tapi apabila seorang pengedar ingin bersih dari narkotika, maka kami pihak BNN akan membantu dan melakukan tindakan rehabilitasi ini di LAPAS.

Himbauan dengan sulitnya untuk membedakan pecandu dan pengedar maka akan lebih baik apabila rehabilitasi dilakukan di LAPAS. Putusan hakim akan tetap pada pidananya dan rehabilitasi akan tetap dijalankan di LAPAS. Tapi dalam kasus ini seharusnya seorang pengedar tidak hanya di rehabilitasi saja, karena harus adanya penerapan pidana sebagaimana yang telah disediakan dalam Undang-Undang.

\footnotetext{
${ }^{14)}$ Hasil Wawancara
} 
Tim asesmen terpadu yang dimiliki BNN mempunyai tugas untuk melakukan asesmen atau pemeriksaan baik secara medis maupun hukum. Kedua ini akan memberikan rekomendasi apakah dia murni seorang penyalahguna atau pengedar, tapi tidak bisa secara langsung menetapkan pengedar atau penyalahguna karena tim ini bekerja dengan cepat. Maka akan kembali lagi dari penyidik awal nya untuk memberikan suatu keterangan yang tepat dalam menyidik seorang pengedar atau penyalahguna. ${ }^{15)}$

Hal yang serupa pun juga dinyatakan oleh Menurut Achmad Guntur, S.H. beliau adalah seorang hakim di pengadilan negeri Jakarta Selatan. Beliau menyatakan bahwa setiap perkara hakim menjatuhkan putusan berdasarkan dakwaan, hal ini merupakan suatu prinsip. Ketika suatu perbuatan seseorang yang tidak di dakwakan itu maka hakim tidak mengadili sesuatu yang tidak di dakwakan. Berdasarkan dengan dakwaan dalam putusan tersebut yang di dakwakan adalah pemesanannya, yang dari faktafakta mungkin untuk di pakai sendiri dan tidak untuk diedarkan atau diperjual-belikan maka dakwaan yang terbukti di persidangan itulah yang dihukum.

Peran penyidik dalam hal ini sangat penting, karena penyidik harus berhati-hati dalam melakukan tugasnya untuk menyidik mengenai tersangka yang telah melakukan suatu tindak pidana, harus diketahui apakah hanya itu saja perbuatan yang dilakukan oleh tersangka atau apakah tersangka menutupi sesuatu yang menguntungkan diri sendiri. Dalam hal yang berkaitan dengan kasus ini bisa terjadi beberapa hal, seseorang yang pengedar tapi bersih tidak menggunakan narkotika, tetapi juga ada seorang pengedar yang sekaligus pemakai. Maka penyidik tentunya perlu lebih tajam dalam menyidik sesuatu karena kedua hal ini berbeda.

Seorang pengguna tidak perlu di rehabilitasi apabila dia tidak kecanduan. Apabila dapat dibuktikan dari pernyataan asesmen bahwa seseorang ini perlu di rehabilitasi berdasarkan dengan tingkat pemakaiannya maka harus di rehabilitasi. Namun, apabila tidak terbukti dapat di rehabilitasi maka harus di pidana. Intinya

\footnotetext{
${ }^{15)}$ Hasil Wawancara
} 
pengguna harus disembuhkan memang terdapat Undang-undang yang mengatur untuk dipidana namun tetap harus disembuhkan apabila kecanduan.

Membedakan suatu pengedar dan pengguna memang sulit, maka tidak boleh ceroboh dalam penangkapan dan data pun juga harus lengkap, karena dari data tersebut dapat dilihat apakah orang ini pengedar atau hanya pengguna. Pengedar tidak boleh di rehabilitasi, pengedar harus dipidana. Tidak ada ketentuan dalam peraturan bahwa pengedar di rehabilitasi. Dengan adanya data yang tidak lengkap maka akan sulit untuk membedakan pengedar dan pengguna.

Berdasarkan dari ketidak lengkapan suatu data maka hakim akan menjatuhkan putusan berdasarkan dakwaan yang dituntut, apabila terbukti bahwa seseorang melanggar Pasal 114 UU Narkotika maka tidak akan mungkin orang tersebut di rehabilitasi, karena sudah jelas bahwa orang ini bisa saja mengedar dengan menjualbelikan narkotika tersebut. Apabila seseorang terbukti pula dengan penggunaan narkotika untuk diri sendiri dan tidak kecanduan maka juga tidak perlu di rehabilitasi bahkan harus dipidana agar jera.

Tindakan rehabilitasi ini harus memperoleh keterangan terlebih dahulu dari dokter bahwa seseorang harus di rehabilitasi, setelah data atau asesmen keluar dan menyatakan bahwa orang ini perlu di rehabilitasi dari hasil pemeriksaannya maka orang tersebut baru bisa di rehabilitasi. Apabila ia mempunyai narkotika dengan berat yang melebih batas untuk di rehabilitasi dan dapat dibuktikan di persidangan bahwa orang itu juga mengedar, maka akan berat hukumannya karena orang ini terbukti sebagai pengedar. ${ }^{16)}$

Hery Pujiono selaku penyidik muda di Badan Narkotika Nasional Provinsi DKI Jakarta (BNNP DKI), Jakarta Selatan berpendapat bahwa terdakwa dalam putusan sudah memenuhi unsur berdasarkan fakta dari mengimpor, dan berat narkotika melewati ketentuan SEMA Nomor 4 Tahun 2010 wajib ditahan, karena unsur sudah sangat jelas bertentangan dengan ketentuan Undang-Undang yang ada. Dalam

\footnotetext{
${ }^{16)}$ Hasil Wawancara
} 
membedakan pengedar atau pecandu dapat dilihat dari saat penangkapan, perbuatan apa yang sedang dilakukan oleh seseorang yang tertangkap tangan. Mungkin sedang adanya transaksi jual-beli, sedang memakai. Hal ini dapat membedakan seseorang tersebut pengedar atau penyalahguna. ${ }^{17)}$

\section{B. Analisa}

\section{Aspek Penegakan Hukum Terhadap Pengedar Narkotika dengan Berat Netto 36 Gram}

Peraturan dibuat untuk mengupayakan tercapainya ketertiban dan keteraturan agar suatu negara dapat berjalan dengan baik. Selain itu dibentuknya suatu peraturan juga agar masyarakat dapat mengerti batasan-batasan dari berbagai kepentingan yang melekat pada dirinya. Peraturan bagi negara itu dibuat untuk dipatuhi bukan untuk dilanggar.

Penegakan Hukum sebagai suatu proses, pada hakikatnya merupakan penerapan diskresi yang menyangkut membuat keputusan yang tidak secara ketat diatur oleh kaidah hukum. Esensi dari penegakan hukum itu sendiri (faktor):

1. Faktor hukumnya sendiri, yang di dalam tulisan ini akan dibatasi pada Undang-Undang saja.

2. Faktor penegak hukum, yakni pihak-pihak yang membentuk maupun menerapkan hukum.

3. Faktor sarana atau fasilitas yang mendukung penegakan hukum.

4. Faktor masyarakat, yakni lingkungan dimana hukum tersebut berlaku atau diterapkan.

5. Faktor kebudayaan, yakni sebagai hasil karya, cipta dan rasa yang didasarkan pada karsa manusia di dalam pergaulan hidup.

Pada hakikatnya kegiatan penegakan hukum tidak lepas dari penyerasian antara nilai-nilai yang ada pada masyarakat. Penegakan hukum dan keadilan merupakan masalah klasik hukum yang melibatkan serangkaian proses yang cukup panjang dan dapat melibatkan berbagai kewenangan instansi/aparat penegak hukum lainnya (di

\footnotetext{
${ }^{17)}$ Hasil Wawancara
} 
bidang penegakan hukum pidana melibatkan aparat penyidik/kepolisian, aparat penuntut umum/kejaksaan, aparat pengadilan, dan aparat pelaksana pidana).

Penegakan hukum terhadap tindak pidana nartkotika diharapkan mampu menjadi penangkal terhadap meluasnya jaringan perdagangan gelap serta peredaran narkotika. Akan tetapi, pada kenyataannya berbanding terbalik. Yaitu semakin intensif dilakukan penegakan hukum, semakin meningkat pula peredaran serta perdagangan gelap narkotika tersebut.

Meskipun pemberantasan narkotika semakin giat dilakukan baik melalui pemberian pemahaman melalui penyuluhan bahaya narkotika maupun dengan pengaturan hukum melalui perundang-undangan yang telah berlaku. Penegakan hukum terhadap tindak pidana narkotika telah banyak dilakukan oleh aparat penegak hukum juga tidak banyak yang telah diputuskan oleh Hakim.

Idealnya, memang putusan Hakim harus memuat idee des recht yaitu 3 unsur sebagai berikut:
a. Keadilan (Gerechtigkeit)
b. Kepastian Hukum (Rechtsicherheit) dan
c. Kemanfaatan (Zwechtmassigkeit)

Hal tersebut pada kenyaataanya memang sulit untuk diterapkan Hakim pada setiap putusannya secara proposional. Seperti yang kita ketahui bahwa aspek penegakan hukum dalam berbagai kajian sistematis penegakan hukum dan keadilan, secara teoretis menyatakan bahwa efektivitas penegakan hukum baru akan terpenuhi apabila 5 pilar hukum dapat berjalan dengan baik. Lima pilar hukum itu adalah instrumen hukum, aparat penegak hukum, peralatannya, masyarakat dan birokrasi. Secara empirik, efcktivitas penegakan hukum juga telah dikemukakan oleh Walter C. Reckless, yaitu harus dilihat bagaimana sistem dan organisasinya bekerja.

Pada hakikatnya, penegakan hukum adalah dimaksudkan untuk mewujudkan nilai-nilai atau kaidah-kaidah yang di dalamnya mengatur tentang prinsip keadilan dan kebenaran. Oleh karenanya, penegakan hukum tidak hanya semata-mata menjadi tugas dari para penegak hukum (kepolisian, kejaksaan, pengadilan, dan 
pengacara/advokat) yang sudah dikenal secara konvensional. Melainkan juga menjadi tugas dari setiap warga negara.

Hal yang berbeda terjadi pada penegakan hukum dalam praktiknya sehari-hari yang dilakukan oleh aparat penegak hukum dan juga oleh masyarakat, karena masih ada penegakan hukum yang semata-mata akan adil apabila ada jaminan yang diberikan oleh orang yang membutuhkan keadilan. Tindak kejahatan yang kerap terjadi dimana-mana tidak membuat jera masyarakat serta aparat penegak hukum untuk menghentikan tingkat kriminalitas yang sudah tinggi.

Kejahatan tidak lagi hanya dilakukan oleh perorangan. Apalagi didorong oleh perkembangan teknologi dan telekomunikasi yang sudah tinggi sehingga lebih memungkinkan tindak kejahatan dilakukan oleh kelompok terorganisir. Untuk menanggulangi segala bentuk kejahatan ini diperlukan suatu penegakan hukum yang tegas agar orang-orang merasa jera dan tidak akan melakukan tindak kejahatan lagi.

Salah satu tindak kejahatan yang dilakukan oleh kelompok terorganisir sama dengan putusan pengadilan negeri Jakarta Selatan yang Penulis analisis mengenai narkotika, dimana kelompok teroganisir ini disebut pemufakatan jahat dalam UU Narkotika Pasal 1 Angka 18 yang adalah perbuatan dua orang atau lebih yang bersekongkol atau bersepakat untuk melakukan, melaksanakan, membantu, turut serta melakukan, menyuruh, menganjurkan, memfasilitasi, memberi konsultasi, menjadi anggota suatu organisasi kejahatan narkotika atau mengorganisasikan suatu tindak pidana narkotika.

Pada Putusan Pengadilan Negeri Jakarta Selatan Nomor 637/Pid.sus/2015/PN.JKT. tindak kejahatan ini dilakukan oleh terdakwa dan kedua temannya yang putusannya splitsing. Terdakwa secara nyata dan meyakinkan telah melanggar Pasal 113 UU Narkotika, karena terdakwa telah memenuhi unsur mengimpor. Unsur mengimpor dalam UU Narkotika Pasal 1 Angka 4 menyatakan bahwa impor adalah kegiatan memasukkan Narkotika dan Prekursor Narkotika ke dalam Daerah Pabean. Daerah pabean adalah wilayah republik Indonesia yang meliputi wilayah darat, perairan dan ruang udara di atasnya, serta tempat-tempat 
tertentu di zona ekonomi eksklusif dan landas kontinen yang di dalamnya berlaku Undang-Undang kepabeanan.

Dari hasil konsultasi Penulis dengan salah satu penyidik bagian reserse narkoba di polres slipi menyatakan bahwa pasal-pasal yang didakwakan kepada terdakwa ini sudah mengarah ke pengedar. Menurut penyidik, pengedar tidak hanya memberikan narkotika golongan I kepada orang lain karena adanya suatu transaksi tapi tanpanya transaksi pun orang ini sudah bisa disebut pengedar. Apalagi dilihat dari berat pun juga sangat besar, dan kami dari pihak penyidik diperbolehkan untuk mencurigai bahwa barang ini bisa saja di edarkan meskipun ada atau tidaknya transaksi untuk memberantas agar peredaran gelap ini tidak semakin menyebar. Begitu pula yang dinyatakan oleh Prof. DR. Lilik Mulyadi, S.H., M.H. Kemudian secara normatif dalam ketentuan UU Narkotika maka pengedar diatur dalam Pasal 111, 112, 113, 114, 115, 116, 117, 118, 119, 120, 121, 122, 123, 124, 125.

Banyak sekali pengedar yang bersembunyi di pasal pecandu agar sanksi yang dikenakan tidak sebesar sanksi dari pasal pengedar. Akibat dari persembunyian yang dilakukan oleh pengedar ini maka menjadi sangat sulit untuk membedakan antara pengedar dan pecandu/penyalahguna. Sangat tidak adil apabila seorang pengedar diberikan putusan rehabilitasi, karena tidak ada ketentuan seorang pengedar di rehabilitasi. Aparat penegak hukum harus lebih waspada dalam menangulangi tindak kejahatan narkotika, karena apabila salah menentukan antara pengedar dan penyalahguna akan sangat tinggi resikonya. Data-data yang dicari harus lengkap dan dibutuhkannya keterangan-keterangan saksi dari pihak tersangka agar dapat diselidiki lebih dalam.

Penegakan hukum dalam tindak pidana narkotika seharusnya tidak boleh ada toleransi, karena apabila adanya toleransi akan memperluas peredaran narkotika baik itu penyalahguna atau pecandu. Semakin banyak pengedar yang lolos dari jeruji besi akan semakin besar dan tinggi pula tingkat penyalahguna atau pecandu di Indonesia. Penegakan hukum dalam tindak pidana narkotika harus tegas sebagaimana telah ditetapkan dalam UU Narkotika. 
Setiap peredaran gelap narkotika meskipun berat barang bukti tidak mencapai 1 kg, hakim harus tetap mempertimbangkan SEMA Nomor 4 Tahun 2010, agar tidak semua orang yang terjerat kasus narkotika dijatuhi putusan rehabilitasi, karena mungkin saja orang ini memang biasanya mengedarkan narkotika dalam ukuran besar namun saat penangkapan barang bukti yang ditemukan kecil. Fakta-fakta yang ada harus dipertimbangkan, agar tidak terjadi peredaran narkotika yang lebih besar.

Sebagaimana yang ditanggapi oleh Hery Pujiono selaku penyidik muda dari BNN yang menyatakan bahwa beliau akan sangat kecewa apabila penyidik sudah berusaha menangkap pengedar namun hakim tetap menjatuhkan putusan rehabilitasi terhadap pengedar, karena menurut beliau tanpa adanya transaksi pun apabila orang ini memberikan kepada temannya akan tetap dinyatakan sebagai pengedar. Bahkan dalam putusan pun sudah dinyatakan dalam keterangan saksi bahwa temannya ini selaku saksi pernah mendapatkan narkotika golongan I hasil pemberian dari terdakwa.

Sudah sangat jelas bahwa terdakwa adalah seorang pengedar yang wajib di tahan bukan di rehabilitasi, karena tidak ada ketentuan bahwa pengedar di rehabilitasi. Namun apabila terdapat seorang pengedar yang ingin di rehabilitasi. Rehabilitasi akan dilaksanakan di LAPAS, jadi penerapan pidana pun tetap jalan dan pengobatan pun tetap jalan. Hal ini telah dinyatakan oleh kepala bidang rehabilitasi dari BNN, dr. Wahyu Wulandari, M.Si.

\section{Hakim menjatuhkan putusan rehabilitasi terhadap pengedar narkotika dengan berat netto 36 gram pada Putusan Pengadilan Negeri Jakarta Selatan Nomor 637/Pid.Sus/2015/PN.JKT.SEL}

Rehabilitasi terdapat 2 macam menurut UU Narkotika yang dibedakan dalam Pasal 1 Angka 16 dan Angka 17 yaitu rehablitasi medis dan rehabilitasi sosial. Rehabilitasi medis adalah suatu proses kegiatan pengobatan secara terpadu untuk membebaskan pecandu dari ketergantungan narkotika. Rehabilitasi sosial adalah suatu proses kegiatan pemulihan secara terpadu, baik fisik, mental, maupun sosial, 
agar bekas pecandu narkotika dapat kembali melaksanakan fungsi sosial dalam kehidupan masyarakat.

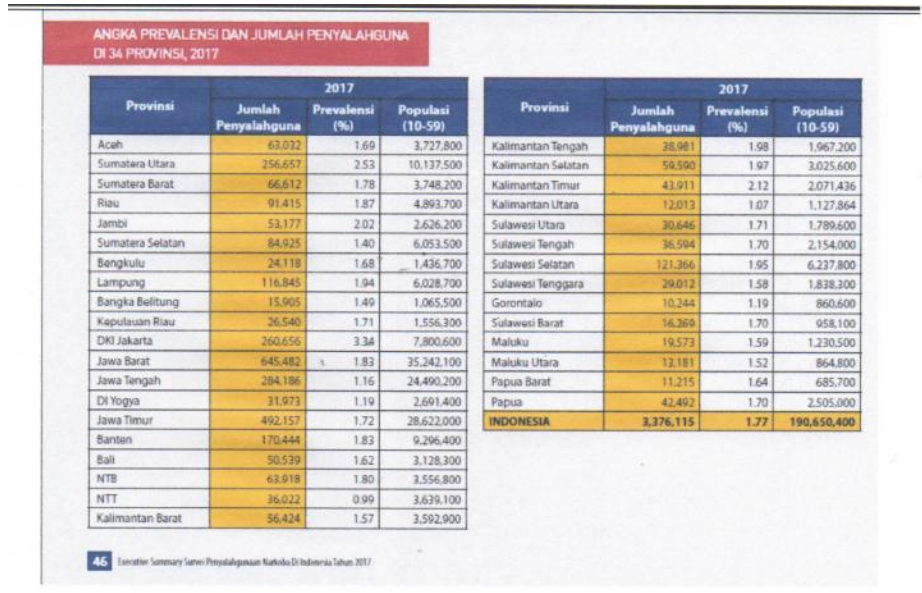

Gambar 1. Angka Prevelensi dan Jumlah Penyalahguna di 34 Provinsi, 2017 sumber : BNN

Berdasarkan dari hasil penelitian yang dilakukan oleh pihak BNN pada tahun 2017 terakhir ini terdapat 3,376,115 jumlah orang yang dikategorikan sebagai penyalahguna narkotika dari 190,650,400 populasi yang berumur 10-59 tahun yang terdapat di Indonesia. Namun hanya 699 jumlah orang yang berhasil di rehabilitasi oleh pihak BNN. Sangat disayangkan karena jumlah orang yang berhasil di rehabilitasi sangat sedikit dari jumlah penyalahguna narkotika. Sangat bertolak belakang sekali. Maka dari itu tindak kejahatan narkotika ini perlu dipertegas penegakan hukumnya dan harus di mulai dari seorang pengedar yang diberi pidana sesuai dengan ketentuan dalam UU Narkotika.

Hal yang dilakukan apabila penegakan hukum sangat tegas dalam menangani kasus narkotika, maka akan sangat dimungkinkan menurunnya tingkat pemakaian narkotika oleh masyarakat. Harus dimulai dari seorang pengedar yang dikenakan pidana, agar peredaran semakin menurun dan para pecandu dan penyalahguna pun juga perlu dikenakan sanksi atau pengobatan agar merasa jera dan tidak mau untuk menggunakan narkotika lagi. 
Sebagaimana penjelasan dalam UU Narkotika telah jelas mengatur pengertian mengenai rehabilitasi yang hanya disediakan untuk seorang pecandu, bahkan rehabilitasi juga dapat diberikan kepada seorang yang dinyatakan sebagai korban penyalahgunaan narkotika. Untuk mendapatkan pengobatan rehabilitasi ini seseorang pecandu yang cukup umur dapat melaporkan diri atau dilaporkan oleh keluarganya ke pusat kesehatan masyarakat, rumah sakit, bahkan dapat melapor ke BNN. Hal ini sudah diatur dalam UU Narkotika Pasal 55.

Pihak BNN akan memberikan bantuan bagi seseorang yang melaporkan dirinya untuk meminta pengobatan agar lepas dari narkotika. Berbeda dengan kasus yang tertangkap tangan dan ditemukan barang narkotika dengan berat yang melebihi dari ketentuan rehabilitasi menurut SEMA Nomor 4 Tahun 2010.

Hal yang terjadi pada Putusan Pengadilan Negeri Jakarta Selatan Nomor 637/Pid.Sus/2015/PN.JKT.SEL. terdakwa tertangkap tangan membawa narkotika golongan I dengan berat netto 36 gram, dan menurut keterangan terdakwa pun barang narkotika ini bukanlah barang yang berasal dari Indonesia melainkan dari Amerika. Namun hakim dalam kasus ini menjatuhkan putusan rehabilitasi selama 1 (satu) tahun kepada terdakwa.

Sebagaimana yang dinyatakan oleh Silas Dutu, S.H., M.H. bahwa narkotika golongan I ini bukan barang yang berasal dari Indonesia melainkan berasal dari Amerika dan terdakwa sudah sangat jelas melanggar Pasal 113 UU Narkotika karena sudah mengimpor barang narkotika golongan I ini masuk ke Indonesia. Hal ini sudah dinamakan penyelundupan obat-obatan terlarang yang mengakibatkan terdakwa dapat disebut sebagai seorang pengedar.

Sedangkan berdasarkan SEMA Nomor 4 Tahun 2010 syarat rehabilitasi pada narkotika golongan I jenis daun koka ini hanya dapat di rehabilitasi apabila pemakaiannya tidak melebih 5 gram sedangkan barang bukti yang ditemukan dengan berat netto 36 gram yang seharusnya terdakwa tidak dijatuhi putusan rehabilitasi melainkan di pidana penjara paling sedikit lima tahun. 
Memang sulit untuk membedakan pengedar dan pecandu atau penyalahguna narkotika, tapi menurut Achmad Guntur, S.H. pengedar itu tidak boleh di rehabilitasi, tidak ada ketentuan untuk pengedar di rehabilitasi maka dari itu data harus lengkap ditemukan dalam penyidikan, agar dalam persidangan hakim mudah untuk menjatuhkan putusan dimana sesuai dari dakwaan yang diberikan oleh jaksa sudah terdapat bukti yang memadai.

Pertimbangan hakim yang menyatakan: menimbang, bahwa dalam dakwaan, Terdakwa didakwa oleh Jaksa Penuntut Umum dengan dakwaan yang disusun secara alternatif, maka Majelis akan mempertimbangkan Dakwaan yang paling terbukti dipersidangan yaitu melanggar Pasal 127 ayat (1) huruf a UU Narkotika, yang unsur-unsurnya adalah sebagai berikut :

1. Setiap orang.

2. Penyalahguna Narkotika Golongan I bagi diri sendiri ;

Meskipun hakim menyatakan demikian, akan tetapi menurut SEMA Nomor 4 Tahun 2010 Angka 2 dinyatakan bahwa penerapan pemidanaan sebagaimana dimaksud dalam Pasal 103 Ayat 1 huruf a dan b UU Narkotika hanya dapat dijatuhkan pada klasifikasi tindak pidana sebagai berikut :

a. Terdakwa pada saat ditangkap oleh penyidik Polri dan penyidik BNN dalam kondisi tertangkap tangan ;

b. Pada saat tertangkap tangan sesuai butir a diatas ditemukan barang bukti pemakaian I (satu) hari dengan perincian antara lain sebagai berikut :
1. Kelompok metamphetamine (shabu)
: 1 gram
2. Kelompok MDMA (ekstasi)
3. Kelompok Heroin
$: 2,4$ gram $=8$ butir
4. Kelompok Kokain
$: 1,8$ gram
5. Kelompok Ganja
$: 1,8$ gram
6. Daun Koka
$: 5$ gram
7. Meskalin
$: 5$ gram
8. Kelompok Psilosybin
:5 gram
9. Kelompok LSD (d-lysergic acid diethylamide)
:3 gram
10. Kelompok PCP (phencyclidine)
11. Kelompok Fentanil
:2 gram
:3 gram
:1 gram 
12. Kelompok Metadon

13. Kelompok Morfin

14. Kelompok Petidin

15. Kelompok Kodein

16. Kelompok Bufrenorfin
$: 0,5$ gram

$: 1,8$ gram

$: 0,96$ gram

:72 gram

:32 mg

Sebagaimana yang telah ditentukan dalam SEMA Nomor 4 Tahun 2010 ini bahwa syarat rehabilitasi tidak boleh melebihi dari berat 5 gram, sedangkan dalam kasus ini terdapat barang bukti 36 gram dengan total 15 barang bukti dalam satu paket tersebut. Kemudian dalam pertimbangan hakim selanjutnya yang mempertimbangkan bahwa alak bukti yang dimiliki sudah cukup akan tetapi menurut literatur atau menurut Sugandi Ishak, S.H., M.H. menyatakan bahwa seorang yang melakukan tindak pidana narkotika tidak dapat di rehabilitasi apabila ditemukan barang bukti diatas 6 gram.

Kasus ini terdakwa juga tidak mendapatkan asesmen dari pihak BNN yang seharusnya menyatakan bahwa terdakwa dapat di rehabilitasi, karena menurut dr. Wahyu Wulandari, M.Si. seorang yang melakukan tindak pidana narkotika akan di periksa terlebih dahulu, apakah seseorang ini memenuhi syarat untuk dilakukannya rehabilitasi atau tidak. Jika hasil dari pemeriksaan tersebut memenuhi syarat maka orang ini dapat mengikuti rehabilitasi dan pihak BNN akan membuat asesmen yang akan diserahkan ke majelis hakim sebagai bukti bahwa orang tersebut membutuhkan pertolongan.

Dalam putusan rehabilitasi pun sangat diperlukan asesmen dari pihak BNN untuk menyatakan bahwa orang ini dapat di rehabilitasi. Apabila tidak adanya asesmen berarti tidak adanya pemeriksaan yang dilakukan di BNN terhadap orang ini, karena setiap penangkapan mengenai tindak pidana narkotika harus dibawa ke BNN untuk diselidiki apakah orang ini berhak atau tidak untuk mendapatkan rehabilitasi, apabila berhak maka BNN akan membuat asesmen yang akan diserahkan kepada hakim di pengadilan sebagai bukti bahwa orang ini membutuhkan pertolongan

Mengingat bahwa sifat hakim dalam acara pidana yang aktif menguatkan bahwa hakim telah lalai dalam memutus perkara ini oleh karena tidak mempertimbangkan 
bahwa terdakwa telah memenuhi unsur mengimpor yang telah memasukan narkotika ke dalam daerah pabean, serta ditemukan barang bukti narkotika golongan I dengan berat netto 36 gram dimana menurut SEMA Nomor 4 Tahun 2010 syarat rehabilitasi tidak boleh melebihi dari 5 gram, serta tidak adanya asesmen dari pihak BNN yang menyatakan bahwa terdakwa telah diperiksa dan dapat di rehabilitasi. Sehingga, sudah seharusnya dan sepantasnya Terdakwa di kategorikan telah memenuhi unsurunsur pengedar dan dikenakan Pasal 113 UU Narkotika yang menyatakan bahwa terdakwa dipidana penjara paling singkat 5 (lima) tahun dan paling lama 15 (lima belas) tahun.

\section{PENUTUP}

\section{A. Kesimpulan}

Berdasarkan pembahasan permasalahan pada bab terdahulu dapat dikemukakan kesimpulan sebagai berikut:

Hakim dalam menjatuhkan Putusan Pengadilan Negeri Jakarta Selatan Nomor 637/Pid.Sus/2015/PN.JKT.SEL. hanya dengan dijatuhkannya putusan rehabilitasi terhadap terdakwa tidak sesuai dengan unsur-unsur dari tindakan yang telah dilakukan oleh terdakwa yang memenuhi unsur-unsur sebagai seorang pengedar. Pertimbangan majelis hakim, sama sekali tidak memperhitungkan adanya unsur mengimpor, barang bukti narkotika golongan I dengan berat netto 36 gram yang tidak sesuai dengan ketentuan dari SEMA Nomor 4 Tahun 2010 yang hanya memberikan syarat rehabilitasi kepada seorang dengan barang bukti yang tidak lebih dari 5 gram, hakim juga tidak memperhatikan ada atau tidak nya asesmen yang harus dibuat oleh pihak BNN untuk memeriksa terdakwa apakah layak atau tidaknya untuk direhabilitasi. Dimana seharusnya hakim memperhatikan Pasal 113 UU Narkotika untuk menjatuhkan pidana paling singkat 5 (lima) tahun dan paling lama 15 (lima belas) tahun. Karena dari unsur-unsur yang dilakukan oleh terdakwa tidak memenuhi syarat rehabilitasi, sedangkan terdakwa juga adalah otak dari sindikat kejahatan yag dilakukan bersama kedua temannya. 


\section{B. Saran}

Berdasarkan kesimpulan di atas, dapat dikemukakan saran sebagai berikut:

1. Penyidik dalam melakukan tugasnya harus tegas dan tidak boleh cerobah dalam mencari keterangan dari tersangka untuk menemukan data yang dapat menjadi kunci utama agar dapat mempermudah dalam membedakan antara pengedar dan pecandu atau penyalahguna narkotika.

2. Majelis hakim dalam menjatuhkan putusan harus berhati-hati dan cermat dalam kasus tindak pidana narkotika, karena banyak pengedar yang bersembunyi di pasal pecandu dan penyalahguna agar sanksi pidana yang di terima terdakwa tidak berat.

3. Majelis hakim harus mempertimbangkan SEMA Nomor 4 Tahun 2010 dalam menjatuhkan putusan rehabilitasi terhadap terdakwa yang melakukan tindak pidana narkotika.

\section{DAFTAR PUSTAKA}

A. Buku

Ali, Achmad dan Heryani, Wiwie. Menjelajahi Kajian Empiris Terhadap Hukum. (Jakarta: Kencana Prenada Media Group, 2012).

Arief, Barda Nawawi. Masalah Penegakan Hukum dan Kebijakan Hukun Pidana dalam Penanggulangan Kejahatan. (Jakarta: Kencana Prenada Media Group, 2008).

Kaligis, O.C. dan Associates. Narkoba dan Peradilannya di Indonesia. (Bandung: Alumni, 2002).

Komisi Yudisial Republik Indonesia. Membumikan Tekad Menuju Peradilan Bersih. (Jakarta: Komisi Yudisial Republik Indonesia, 2011).

Makarao, Taufik. Tindak Pidana Narkotika. (Jakarta: Ghalia Indonesia, 2003). 
Soekanto, Soerjono. Pengantar Penelitian Hukum. (Jakarta: Universitas Indonesia, 2006).

Soemitro, Ronny Hanitijo. Metodologi Penelitian Hukum. (Jakarta: Ghalia Indonesia, 1983).

B. Peraturan Perundang-undangan

Indonesia. Undang-Undang Nomor 8 Tahun 1981 tentang Hukum Acara Pidana (Lembaran Negara Republik Indonesia Tahun 1981 Nomor 76, Tambahan Lembaran Negara Republik Indonesia Nomor 3209).

. Undang-Undang Nomor 35 Tahun 2009 Tentang Narkotika (Lembaran

Negara Republik Indonesia Tahun 2009 Nomor 143, Tambahan Lembaran Negara Republik Indonesia Nomor 5062).

. Undang-Undang Nomor 48 Tahun 2009 tentang Kekuasaan Kehakiman

(Lembaran Negara Republik Indonesia Tahun 2009 Nomor 157, Tambahan

Lembaran Negara Republik Indonesia Nomor 5076).

. Surat Edaran Mahkamah Agung No.4 Tahun 2010 tentang Penempatan

Penyalah Guna, Korban Penyalahgunaan dan Pecandu Narkotika Ke Dalam

Lembaga Rehabilitasi Medis dan Rehabilitasi Sosial.

C. Artikel

Pratama, Akhdi Martin. "Pengguna Narkoba di Jakarta Mencapai 1,2 Juta Orang". Kompas. 24 Juli 2017.

Mulyadi, Lilik. "Pemidanaan Terhadap Pengedar dan Penggunan Narkoba". Jurnal Hukum dan Peradilan. Edisi No. 1 Tahun 2012. 